\title{
Spatial Planning in Perspective of Good Governance (A Study on Analysis of Spatial Planning in Batu City as a Tourism City)
}

\author{
Retno Wulan Sekarsari ${ }^{1}$, Andy Fefta Wijaya ${ }^{2}$ \\ ${ }^{1}$ Student of Double Degree Master Program in Faculty Administrative Science Brawijaya University, Indonesia and \\ Faculty of Political Science and Law, Burapha University, Thailand. \\ ${ }^{2}$ The Head of Master Degree Double Program in Public Administration Department, Faculty of Administrative Science, \\ University of Brawijaya, Indonesia.
}

\begin{abstract}
Spatial planning is an effort to improve the welfare of the community and to ensure environmental sustainability by taking into account the comparative advantages in an area and minimizing the development gap by reducing slums, and poor and underdeveloped areas. Regional Spatial Planning Policy is a kind of policy product to control the level of environmental damage and the disorganized development and growth in a city or regency. The role of Batu City Government is to realize Batu City space that is safe, comfortable, productive and sustainable as a superior agropolitan city and tourism city in East Java Province. This article utilized Good Governance Perspective and System Theory to analyze the formulation of Regional Spatial Planning Policy in Batu City. This article firstly explained about tourism development, and secondly described the authority and responsibility of stakeholders in spatial planning formulation. The third part clarified good governance perspective on spatial planning in Batu City and analyzed supporting and inhibiting factors in spatial planning formulation in Batu City. The findings showed that only some actors and factors had strong influence over the formulation of Regional Spatial Planning Policy.
\end{abstract}

Keywords: Good Governace, Governace Perspective, Spatial Planning, Tourism City, Batu City

\section{INTRODUCTION}

According to Larsson (2006) spatial planning is an effort to improve the welfare of the community and to ensure environmental sustainability by taking into account the comparative advantages in an area and minimizing the development gaps by reducing slums area, poor and underdeveloped areas. Urban planning is the determination, and assurance of proportional space utilization so that the area may meet aspects of economic activities, and social environment in the city.

Those three aspects are very important for the safety, prosperity, and progress of the people who live in that area. Batu City Local Regulations Number 3 Year 2004, about Spatial Planning of Batu City Year 2003-2013, Article 3 says Purpose of spatial use is to improve the society welfare and for defensive and security purposes realized through a strategy of spatial use implementation aimed to achieve quality spatial use".

Purpose of spatial uses are to improve the welfare of society through strategy of spatial

\section{Corresponding Address:}

Email : retnowulansekarsari@gmail.com

Address : Woromarto, Melati Street No.18, Purwoasri, Kediri, 64154, Indonesia used in formulation and implementation that aimed to achieved quality spatial used. The purposes of spatial planning are: 1) The implementation of environmentally spatial used; 2) The implementation of spatial used arrangement of protected areas and cultivation areas, and 3) Achieved quality of space utilization.

scenery. However, Batu City government was still not able to package and manage it well. During this time, supports from the community for Batu City development as a tourism city were still weak. Some of them were indifferent to the spatial planning development of Batu City and also the cleanliness of the city, because in general human resources of Batu City community were still weak. Majority of them had low and average education, not high education.

If the regulation would not formulated properly it will make bad policy implementation, because the quality of the regulations that were implemented in the the field was not good. There were so many reasons why the formulation of Regional Spatial Planning Policy was not good. The first reason was the lack the quality of human resources, especially the government officers in Batu City, while the second reason was due to the lack of participation from the policy actors and another stakeholders including social participation. If spatial planning which were 
concerned "plots" were not formulated and implemented properly, disorganization in the city would exist. It would make the growth of slum areas that disrupted transportation system in the city and the difficulty to overcome environmental problems and health impacts resulting from it.

Based on the background above, the research questions in this thesis is how is the spatial planning in Batu City as tourism city in the perspective of Good Governance? The objective of this research is to try to answer the research question. The objective of this research is to describe and analyze the characteristics of spatial planning in Batu City from the perspective of good governance.

\section{METHODS}

\section{Type of Research}

In this research, the researcher used descriptive-qualitative type of research. Hybert Hyman in Koentjaraningrat (1991:29) stated that: "Descriptive research is a research aimed to accurately describe the characteristics of an individual, situation, phenomena, or certain group, or to determine the frequency of a certain relation between a phenomenon with another in the society".

On the other hand, qualitative research method, as proposed by Bogdan and Taylor in Moleong (2005:3) "qualitative method is defined as a research procedure that produces descriptive data in the form of oral or written words from people and observable behaviors".

Research Focus

The focus of this "Spatial Planning in Perspective of Good Governance (A Study on Analysis of Spatial Planning in Batu City as a Tourism City)" research is:

\section{Good Governance perspective on spatial planning in Batu City as tourism city Location and Site Research}

This research is located in Batu City. Batu City is a city in East Java Province. The research sites are in Batu City, especially in the Human Settlement and Spatial Planning Department, Regional Development Planning Agency (BAPPEDA), and Tourism and Culture Departement of Batu City. The sites chose because it fits the title and focus of research that seeks to describe and analyze and interpret those aspects related to the field of spatial planning in Batu City, especially in spatial development view from good governance

Type and Source of Data

Source of Data: a) Primary data is data collected from firsthand source. This data is collected through direct interview with the related party, that are: (1) Human Settlement and Spatial Planning Department of Batu City; (2) Regional Development Planning Agency (BAPPEDA) of Batu City, (3) Tourism and Culture Departement of Batu City and also (4) Batu City's societies (include an expert of spatial planning in Batu City, common society of Batu City and business man in Batu City).

b) Secondary data is data collected from documentation materials and literatures related to the research question. This data is acquired through other people's $h$

c) elp, such as international journals that related with this research, archives, or document from each government institution in Batu City such as Regional Spatial Planning doccument, Batu City in Figure, spatial planning map, etc from Bappeda and Local House of Representative of Batu City

\section{Data Collecting Process}

Data collecting process is the ways that a researcher can use to obtain data (Arikunto, 1990:134). In this research, data collection is conducted with several ways, as the followings:

a) Library Study, conducted by collecting data from a number of references related to spatial planning, good government, tourism city, etc.

b) Field Study, utilizes data collection technique such as observation, interview, and documentation.

\section{RESULTS AND DISCUSSIONS}

1. Good Governance perspective on spatial planning in Batu City as tourism city

Policy input greatly affects the policy output through conversion process. The policy output greatly affects environment and than gives feedback to the systems. There was good policy if input, processes properly would produce good policy output, and reflect good feedback to the systems. This because the four stages are very closely related and could not be separated from one another.

Researcher used the six characteristics of good governance which closely related to this case studies that researcher took in the research "Good Governance Perspective on Spatial Planning in Batu City as a Tourism City". The six characteristics of good governance, namely: (a) Transparency; (b) Rule of law; (c) Openness; (d) Participation; (e) Accountability; And (f) 
Responsiveness. The detail explanation of relationship of this six characteristics of good governance with the policy formulation process in spatial planning policy in Batu City as follows:

\section{a) Transparency.}

Transparency was built on the basis of free flow of information. Processes of institution and informations were directly received by those in need. And below are the interview datas and result from the field:

- Mr. YP, Head of General Sub-section and Staff in Tourism and Culture Department of Batu City "There is no contribution of Tourism and Culture Department in the perspective of transparency yet, because we are still drafting the tourism policies in accord with the policies of the incumbent Mayor". (Interviewed on March 3, 2013).

- Mr. SW, Head of Facility, Infrastructure and Environmental Planning Division, Local Development Planning Agency (Bappeda) Batu City

"The form of transparency from the Bappeda is by cooperating with all stakeholders in the public trial of our policy. Bappeda, BKPRD and all stakeholders are working side-by-side in determining the developmental direction of regional spatial planning policy and in managing the City of Batu. When public trial is conducted, Bappeda and the Municipal of Batu broadcast it on local TV station and radios as a form of transparency. When the policy is passed and legalized by DPRD, it will be published on local newspapers, official websites of the Municipal and Provincial Government of East Java." (Interviewed on March 20, 2013)

- Mr. TW, Executive Drawing Technician in Human Settlement and Spatial Planning Department of Batu City

"Human Settlement and Spatial Planning Department provides socializations to all villages in Batu City about the regional spatial planning policy in the form of Spatial Planning Map". (Interviewed on April 4, 2013)

- Mrs. Y, Public Figure and Environmental Activist in Batu City

Community leaders and all tourism activists in Batu City really support the improvement on the transparency of polices made by the government. As far as I know, the transparency of policy has been clearly shown in the public testing, in which all society members may give criticisms or suggestions. Additionally, the socialization of Regional Spatial Planning Policy map has been running well. Unfortunately, some people are still ignorant or do not really care about it.." (Interviewed on April 04, 2013).

- Mr. BW, Public figure in Batu City, Environmental Activist, and one of the Tourism Village Initiators

The transparency for the spatial planning policy, I think, so far so good. Each step taken by the formulator has always been informed first hand to the society through public testing. In addition, the policy products are always published in the website www.jdih.jatimprov.go.id. Unfortunately, not everybody knows about this website. I can say that the socialization on the website, for people to download the policy products, is still lacking." (Interviewed on April 04, 2013).

\section{b) Rule of law.}

The legal framework should be fair and carried out indiscriminately, particularly human rights law. Principles of rule of law had the characteristic form of guarantee of legal certainty and sense of justice against any public policy that was made and implemented. And below are the interview datas and result from the field:

- Mr. SW, Head of Facility, Infrastructure and Environmental Planning Division, Local Development Planning Agency (Bappeda) Batu City

"Legal basis for regional spatial planning policy in Batu City refer to Act no. 26 Year 2007 on spatial planning and Regulation of the Ministry of Public Works no. 20 Year 2011 on regional spatial planning policy and Detailed City Spatial Plan that may be modified every 20 years". (Interviewed on March 20, 2013)

- Mr. DF, Expert on Spatial Planning and Head of Treatise Section in Local House of Representatives (DPRD) of Batu City

"Legal basis on spatial planning policy start from Local Regulation, elaborated in more detailed in the regulation of the mayor which also functions as the implementation guideline and local regulation (Mayor Decree) that serves as technical guidelines." (Interviewed on March 25, 2013)

c) Openness.

The decision-making institutions should work in open manner. Government should actively communicate with the other stakeholders, such as society, private sector and NGOs about what government should do and should decide. Below are the interview datas and result from the field:

- Mr. YP, Head of General Sub-section and Staff in Tourism and Culture Department of Batu City 
"Anybody who requests data regarding tourism in Batu City will always be granted, whether they are students, community members, NGOs pr businessmen, as long as they adhere to the existing procedures and regulations. Tourism and Culture Department is very much open to any society member who wants to access tourism data". (Interviewed on March 3, 2013)

- Mr. S, Expert on Spatial Planning and Head of Treatise Section in Local House of Representatives (DPRD) of Batu City

"The openness of DPRD is reflected on each phase of the policy to be passed into a local regulation. It always undergoes public trial phase, to listen to all aspirations, criticisms and suggestions of the society and all related stakeholders." (Interviewed on April 4, 2013)

- Mr. BW, Public figure in Batu City, Environmental Activist, and one of the Tourism Village Initiators

The government's openness is really clear when the activists ask for data to them to evaluate the on-going tourism developments and also ask data and information related to spatial planning." (Interviewed on April 04, 2013).

- Mrs. Y, Public Figure and Environmental Activist in Batu City

The government's openness is shown by all institutions/offices when they become the subject or reference source for research, information and data.." (Interviewed on April 04, 2013).

d) Participation.

Every citizen had voice in decision making, either directly or through legitimate intermediate institutions that represent their interests. Such participation was built on the basis of freedom of association, speech and constructive participation. Participation was also empowerment process of people power in the development and community participation or community awareness. Participation was also one of the measurement of democracy. Below are the interview datas and result from the field:

- Mr. SW, Head of Facility, Infrastructure and Environmental Planning Division, Local Development Planning Agency (Bappeda) Batu City

"Bappeda cooperates with BKPRD who responsible for formulating policy and designing the spatial planning policy. Afterwards, the spatial planning policy draft is introduced and publicly tested to society and related stakeholders. However, those stakeholders tend to be passive. When there is no policy product introduced or publicly tested, they are reluctant to provide feedbacks or inputs to the existing spatial planning policy. Therefore, Bappeda must also participate as the formulator of spatial planning policy". (Interviewed on March 20, 2013)

- Mr. TW, an Executive Drawing Technician in Human Settlement and Spatial Planning Department of Batu City

"Participation of Human Settlement and Spatial Planning Department is by providing technical considerations to Bappeda. In making Regional Spatial Planning Policy, Urban Spatial Planning Section provides technical inputs regarding spatial planning and zoning planning. Additionally, Human Settlement and Spatial Planning Department also participates in making draft for Regional Spatial Planning Policy Control". (Interviewed on April 4, 2013)

- Mr. BW, Public figure in Batu City, Environmental Activist, and one of the Tourism Village Initiators

"Society participation in Regional Spatial Planning Policy formulation is by expressing our voices in the public trial. Society gives criticisms and suggestions on the publicly tested policy draft. However, most of the society members always give their approval and support to any policy made by the government, without any criticism or suggestion, because most of us take passive stand. If the policy is good, it will proceed. If it is not, then we will say something". (Interviewed on April 04, 2013).

e) Accountability.

Accountability was hold the calculation of the resources or authority that used. Accountability was required to provide an explanation for what had been done. Below are the interview datas and result from the field:

- Mr. SW, Head of Facility, Infrastructure and Environmental Planning Division, Local Development Planning Agency (Bappeda) Batu City

"The role and accountability of Bappeda in making Regional Spatial Planning Policy is to process all draft inputs from all local government institutions to become a local regulations, especially the Regional Spatial Planning Policy. The role and responsibility of Bappeda can be described as the policy 'chef' who concocts and formulates policies. On the other hand, other local government institutions and stakeholders (all agencies, communities, private sector, local officials, and academics) 
are in charge of making drafts (policy material/input) and give criticisms and suggestions which will later be processed to become a policy product, namely spatial planning." (Interviewed on March 20, 2013)

- Mr. TW, Executive Drawing Technician in Human Settlement and Spatial Planning Department of Batu City

"Accountability of the Human Settlement and Spatial Planning Department in making spatial policy is to conduct monitoring, evaluation and socialization. Evaluation and monitoring is carried out by consultants who work together with Human Settlement and Spatial Planning Department in executing these tasks. So, it is not solely conducted by Human Settlement and Spatial Planning Department" (Interviewed on April 4, 2013).

- Mr. NW, Head of Urban Spatial Planning Section in Human Settlement and Spatial Planning Department of Batu City

"In the development of Batu City, the main responsibility remains in the hands of the Mayor. Local House of Representatives (DPRD) only receives reports from the Mayor. The Mayor is supported by a support team called Local Spatial Planning Coordination Office or BKPRD whose responsibility is to give technical considerations to the Mayor about control and urban planning in Batu City. Major may also appoint building experts to give technical considerations. The Human Settlement and Spatial Planning Department functions as the coordinator for facilities and infrastructures development in the Batu City, but Human Settlement and Spatial Planning Department remain responsible to the Mayor." (Interviewed on March 19, 2013).

\section{f) Responsiveness.}

City government should try to cater every stakeholder. Government should response quickly to the needs of the community. Government should pay attention to the people. Below are the interview datas and result from the field:

- Mr. YP, Head of General Sub-section and Staff in Tourism and Culture Department of Batu City "When the Tourism and Culture Department wants to issue an activity or policy, we always conduct internal meeting first, for example with the Tourism Awareness (Darwis) groups, tourism villages, etc, depending on what we are going to issue." (Interviewed on March 3, 2013)

- Mr. SW, Head of Facility, Infrastructure and Environmental Planning Division, Local
Development Planning Office (Bappeda) of Batu City

"Bappeda is very responsive in listening to criticisms, suggestions, and aspirations of the society and all stakeholders, especially during public testing, which is attended by all stakeholders and Representatives of the society." (Interviewed on March 20, 2013)

- Mr. TW, Executive Drawing Technician in Human Settlement and Spatial Planning Department of Batu City

"Anybody who requests to access documents on regional spatial planning policy and documents on regional spatial planning policy control is always responded positively. All elements of the society may access all data, as long as they follow the existing procedures and requirements." (Interviewed on April 4, 2013)

- Mr. BW, Public figure in Batu City, Environmental Activist, and one of the Tourism Village Initiators

"In my opinion, the Government of Batu City has been very responsive in dealing with complaints or aspirations from the society. Its proven when we (environmental and tourism village activists) asked for the help of tutors to improve the performance of SMB and Human Resources of the local people, the Government of Batu always sent their personnel from the Labor Office. In addition, I think that the Government of Batu City always listens to the society's aspiration conveyed through the public testing." (Interviewed on April 04, 2013).

- Mrs. Y, Public Figure and Environmental Activist in Batu City

The responsiveness of the Government of Batu City, as far as I know, is reflected in their quick response when problem arises or when they receive reports from the society/village apparatus, such as obstacles in improving human resources/SMB and other issues related to spatial planning." (Interviewed on April 04, 2013).

Based on the research results and all of data's, we could learn about the six characteristics of good governance that still weak in processes of spatial planning policy formulation in Batu City as tourism city. We could also identify which aspects that had passive role in the formulation of spatial planning in Batu City. Thus, we could conclude that:

\section{Transparency}


Transparency was quite good in so many aspect, such as in cooperation among stakeholders in "public test", in provide socialization about spatial planning to society in every villages in Batu City.

Transparency and cooperation among various stakeholders could be seen in the public tests and how they broadcast in the local TV station, and radios. When the policy was passed and validated by the Local House of representative (DPRD), they would publish it in the local newspapers, official Municipal website, and official Provincial website of East Java Province. On www.jdih.jatimprov.go.id, every people had privilege to download all of the local regulations that produced by each districts or cities. There was no limitation for people to access the contents in that website because it would made the people to became more awareness on the laws and regulations. Beside that, it would be minimized dissatisfaction or protests towards the Batu City government policies.

Batu City government, especially through Human Settlement and Spatial Planning Department that would be provided socialization through spatial planning maps to every villages in Batu City.

\section{Rule of Law}

Rule of law characteristic very clear in here, because it became legal basis or foundations of formulation of regional spatial planning policy. Act No. 26 Year 2007 on Spatial Planning and Regulation of the Ministry of Public Works No. 20 Year 2011 in the regional spatial planning policy and detailed urban spatial planning as foundations of formulation of regional spatial planning policy of Batu City.

3. Openness

Openness in give the datas of government institutions had been impressive because all government institutions namely Local Development Planning Agency (Bappeda) Batu City, Tourism and Culture Department of Batu City and Human Settlement and Spatial Planning Department of Batu City as subject of this research had shown open attitude to the societies, NGOs, and businessmen who want to access their data's, as long as they follow the existing procedures and regulations.

These institutions had provided positive responses to society who wanted to express their assumptions and freedom of speech in form of suggestions and criticisms in the Public Test forum before the policy draft was validated.

\section{Participation}

Participation was needed in policy formulation and implementation on spatial planning policy of Batu City to make a good policy input and policy process. If there was no participant in policy formulation and implementation, then the policy could not be formulated and implemented well.

In this case, participation had not been so good because the society still passive and just follow the government policies without criticize the essence of the policies because of the weak of human resources of Batu City people.

The others government institutions beside of Bappeda, had participated by provide inputs and suggestions on the policy drafts that being tested. They also tend to be passive when there was no policy product presented. They only wanted to criticize and give suggestions when there was policy drafts being publicly tested without any initiatives to give inputs and suggestions.

If this condition continues, it would be produced negative impacts in the Batu City development because it lack of inputs for their policies. Without sufficient inputs it would negatively affect policy process and policy outputs and it would given adversely affect to the society itself.

\section{Accountability}

Accountability was needed in every stage of policy making, not only in policy formulation and implementation because the government should be responsible with the decision that taken in every stage of policy. In terms of accountability, especially in public test, all institutions namely Local Development Planning Agency (Bappeda) Batu City, Tourism and Culture Department of Batu City and Human Settlement and Spatial Planning Department of Batu City had been worked very well according to their own tasks and functions and had been supported one another.

\section{Responsiveness}

Responsiveness was needed, especially in the process of policy formulation. Government policy should encompass all inputs from all stakeholders, especially from the society. Therefore, the government had to responsive to the complaints or problems 
that exist in the community. The government had to quick and responsive to answer the needs of the community.

This responsive attitude had been shown in almost all institutions in Batu City in the public test. In general, they had been responsive and listen the aspirations and complaints of society. in the public test.

All stakeholders were invited, including society, private sector, public figure, Local Development Planning Agency (Bappeda) Batu City, Tourism and Culture Department of Batu City and Human Settlement and Spatial Planning Department of Batu City, another government institutions, etc. In the Public Test, they could freely provide criticisms and suggestions or inputs on the policy draft that being tested.

\section{Prior Research}

1. Obstacles to Heritage Tourism Planning: Socio-Spatial Planning Problems in Mardin by Elif Gunduzi, Rahmi Erdemi, 2010. The result of finding is strategic integration and coordination of all tourism related planning and activity is vital for the creation of sustainable tourism marketing management that delivers social, economic and environmental wellbeing. In the process of tourism development, Ministry of Culture and Tourism, should make sustainability principles inseparable and integrated elements of planning and implementation. The implementations that enable the local people to be prioritized in participation of the employment should be included in the planning (such as promoting boarding housing, creating a souvenir sector for the improvement of local products, training people to work in guidance and touristic services, inciting the third party investors to employ common people and developing agricultural tourism).

2. The Systemic Location of Tourist Elements in the Integrated Spatial Planning. Case Study: The Outskirts of BistriŃa Municipality by Vasile Zotic, Viorel Puiu, Diana Elena Alexandru, 2011. The multitude of regulations regarding the common spatial strategic planning in Romania and European countries challenge the public administrations to properly manage the land, inside and outside the borders of a city or village, and give optimal functionality to areas in accordance to their natural and anthropogenic potential. Much more, the attempts for elaborating such territorial analyses, which are considered the step towards sustainable development, are financially supported by the local budgets of the administrative-territorial units and other private or public bodies.

If this case compared with prior research to see another spatial planning problems in Batu City, we will find this point:

1) The implementation that enabled the society to promote public participation in the planning process (such as promoting boarding house, creating souvenirs for the improvement of local products, training village people to work as guide and tourist service providers, giving some influence to investors to employ village people, and developing agricultural tourism).

2) Investors, and local government should properly manage the land, inside and outside the borders of a city and give optimal functionality to areas in accordance with their natural potentials. The attempts for elaborating such territorial analysis, which are considered step towards sustainable development, financially supported by the local budgets of the administrative territorial units and other private or public bodies. And we should always remember that development is not only designed for tourism development, but also become feasible choice and answer for future social and economic coherence and rational evolution.

\section{CONCLUSION}

Transparency was good in the aspects of cooperation among stakeholders in "public test", and in provide socialization about spatial planning to society in every villages in Batu City. we can see and analize the foundations of formulation of regional spatial planning policy (Rule of Law) of Batu City from . Act No. 26 Year 2007 on Spatial Planning and Regulation of the Ministry of Public Works No. 20 Year 2011. Openness characteristic in this case showed on the easy system that government institutions gave to all of stakeholder to access their data's. They also had provided positive responses in public test to listen and accept suggestions and criticisms. In the participation aspect still weak, because they still passive and just follow the government policies without criticize the essence of the policies because of the weak of human resources. In terms of accountability, especially in public test, all of government instituions had 
been worked very well according to their own tasks and functions and had been supported one another. Responsive in this case had been shown in almost all institutions in Batu City in the public test, because they had been responsive and listen the aspirations and complaints of society.

From the conclusions that had been derived above, there were some suggestions which could be proposed for consideration. Those suggestions as follow:

1) Batu City government and all of local work unit (SKPD) had to improve the socialization and give many information concerning with regional spatial planning policy and all of the roles in regional spatial planning policy. It could be improved deep understanding about regional spatial planning policy of Batu City's people especially for the people who live in villages and come from low class. And it would make them obey regional spatial planning policy, so that there was no violation and conflict about spatial planning.

2) Batu City government and all of local work unit (SKPD) had to improve the socialization to increase the level of participation in term of societies and private sectors. Batu City government had to give deep explanation to them that participation (such as give criticisms and suggestions to Batu City government) was very important as an policy input to arrange the local policy regulation. Batu City government had to explain that the participation of the very important in Public Test to get a good policy input, to improve the quality policy formulation spatial planning, and improve the accountability and also transparency of Batu City government in formulate spatial planning policy.

3) Batu City's government officers (especially the member of Local House Representatives) should join in short course continuously, and comparative study to the others cities to improve them understanding about urban design science and regional spatial planning policy. In government level, the quality of human resources was very important, because human resources were a tools in product some policies and an activator, and determine production process. Human resources brought the main role in determine progress and development of government institution. Therefore, the progress of government institutions development determined by the quality of human resources inside of government institutions.

\section{ACKNOWLEDGEMENT}

I would like to express my special thanks to Allah as creator of my life for His blessings and guidances, and my parents, and my advisor Drs. Andy Fefta Wijaya, MDA, Ph.D who have patiently guided me in completing this research so that I could finish my research entitle Spatial Planning in Perspective of Good Governance (A Study on Analysis of Spatial Planning in Batu City as a Tourism City).

Secondly, I am also thankful to Regional Development Planning Agency (BAPPEDA) of Batu City, Human Settlement and Spatial Planning Department of Batu City, Tourism and Culture Departement of Batu City, and all of civil servants in Batu City for their participation in completing interview data's in this research.

Indeed, my thankfulness is forwarded to commune leaders and activists as well as the civil society representatives for their contributions and input of experiences and views to my research completion.

\section{REFERENCE}

[1]. Appendix to the Decree of Local House of Representatives Number 11, Year 2011.

[2]. Arikunto, Suharsimi. 1990. Manajemen Penelitian. Jakarta: Rineka Cipta.

[3]. Batu City in Figures, 2011.

[4]. Batu City Local Regulations Number 3 Year 2004, about Spatial Planning of Batu City Year 2003-2013.

[5]. Batu City Local Regulation Number 10, Year 2009 on Tourism.

[6]. Document of Departement Tourism and Culture Batu City, 2012.

[7]. Data of Guest Visits at All Hotels in the Batu City in the Document of Tourism and Culture Department Batu City, 2012.

[8]. End Year Poppulation Registration 2010, in Batu City in Figures 2011.

[9]. International Journal of Obstacles to Heritage Tourism Planning: Socio-Spatial Planning Problems in Mardin by Elif Gunduzi, and Rahmi Erdemi, 2010.

[10]. International Journal of The Systemic Location of Tourist Elements in the Integrated Spatial Planning. Case Study: The Outskirts of BistriŃa Municipality by Vasile Zotic, Viorel Puiu, and Diana Elena Alexandru, 2011.

[11]. Koentjaraningrat. 1991. Metode-Metode Penelitian Masyarakat. Jakarta: PT. Raja Grafindo Persada. 
[12]. Larsson, Gerhard. 2006. Spatial Planning Systems in Western Europe - An Overview. Delft University Press.

[13]. Mayer, Robert R. \& Greenwood, Ernest. 1984. Rancangan Penelitian Kebijakan Sosial. Jakarta: CV Rajawali.

[14]. Moleong, Lexy, J. 2005. Metodologi Penelitian Kualitatif. Bandung: PT. Remaja RosadaKarya.
[15]. Uraiwan, Sanghirun. From Policy Analysis to Policy Formulation and Policy Implementation: The Perspective of The National Education Council, Thailand.

[16]. Widodo, Joko. 2001. Good Governance. Surabaya: Insan Cendekia. 